\title{
Discrimination in Zootopia: A critical reading
}

\author{
Hianly Muljadi* \\ English Department, Faculty of Language and Culture, \\ Universitas Kristen Maranatha, Bandung, Indonesia
}

\section{*Corresponding Author}

Email: hianly.muljadi@gmail.com

\begin{abstract}
This research is an analysis of an animation movie by Walt Disney Animation Studios entitled Zootopia. The story of Zootopia, just like other animation movies which can be generalized as intended for children. It contains a positive message which can be seen from the tagline of this movie; "This is Zootopia. Anyone can be Anything". However, this research tries ascertaining the opposite as it can be seen that the message of the movie is not entirely true. It is under descriptively qualitative method supported by the Theory of Deconstruction as a framework -- that a text can betray itself and this movie is no exception. In Zootopia, just like in human world, the animals are divided into species and kinds or types. This division can clearly lead to discrimination, stereotypes and prejudice. At the end, the notion that anyone can be anything is right to some extend but there are certainly limitations and boundaries that one cannot across to avoid instability in the life of the animals. Thus, the movie can be 'read' as having an entirely different message. This research shows that an animation movie can also be interpreted in many ways and may indeed reflect what happens in our reality.
\end{abstract}

Keywords: animation; discrimination; stereotypes; prejudice; deconstruction

Received: Revised:

19 November 201810 June 2019

Accepted:

Published:

1 July 2019

31 August 2019

\section{INTRODUCTION}

The existence of American popular culture is undeniably true over the world. Film is one of them. Zootopia is an animation movie produced by Walt Disney Pictures and released on March 4, 2016. It has become a box office movie since its first appearance, with the gross of $\$ 527$ million from the market outside America alone (Pressberg, 2016). Moreover, this movie is chosen as one of the top ten movies of 2016 by the American Film Institute (Hipes, 2016). It also has received an Academy Award, Golden Globe, Critics' Choice Movie Award, not to mention many other nominations as the best animation film.

This movie is set in a world of anthropomorphic animals, in an urban city called Zootopia. Although some animals are preys while others are predators, 
all the animals in Zootopia manage to live together side by side in harmony. The movie focuses on the story of a rabbit, named Judy Hopps, who goes from her rural hometown to an urban city, Zootopia, to work as a police officer. Despite being the best student in the police academy, Judy is assigned to parking duty as she is under estimated by her captain because she is the only rabbit ever made it to become a police officer. However, Judy is determined to prove herself worthy and she later on takes part in an investigation of a case about 14 missing predators. In her investigation, Judy gets help from a con artist, Nick Wilde, a fox. Together, they manage to solve the case.

On the surface, Zootopia, which is an animation movie thus, is presumably intended for children. It tells the viewers to set their own dreams and they will be able to get it. There should not be any discrimination, prejudices, or stereotyping that limit what someone can or cannot do. It is seen from the movie's most famous quotation from Judy, which goes 'Anyone can be anything'. This message is also clearly seen from how Judy, who is described as a determined rabbit, refuses to give up her dream of becoming a police officer although everyone else says the otherwise because rabbits are not supposed to be a police officer. She encounters difficulties the first time she enters the police academy but she works very hard and manages to become the very first rabbit police officer. She also faces difficulties in her first days at Zootopia, but again, she manages to overcome her problems and becomes a reputable police officer.

The same case happen to Nick Wilde, the con artist. He succeeds in proving himself that as a fox, he can lead an honest life. He manages to deny the stereotype that all foxes are cunning and deceitful. At the end of the movie, he gives up his 'career' as a con artist and becomes Judy's partner.

Based on that idea, Zootopia offers an ideal life where different kinds of animals can live in harmony without any discrimination, prejudice or stereotyping. Preys and predators can break free from their stigma and prove themselves to be otherwise. Since Judy and Nick manage to overcome those challenges and come out triumphant over those sentiments, the message from this movie is very clear that discrimination, prejudice and stereotyping are wrong and can be eliminated, as also stated in The Observer, that Zootopia is "In fact, ... a delightfully well-orchestrated parable about trust and tolerance versus panic and prejudice. An encouragingly upbeat celebration of love and diversity in times of hate and uncertainty" (Kermode, 2016). Judy and Nick then act as a living proof that the idea is true, that you can be anything you want no matter what type of 'animal' you are.

In this paper, The writer would like to reveal the inconsistencies shown by Zootopia especially concerning the message of equality between species - as the characters in Zootopia are all animals. Even though there are some researches dealing with Zootopia, like Barnes, Erik. "12 Ways Zootopia Addresses Racism in a More Meaningful Way than Most Films." or Pressberg, Matt. "Anti-Racist 'Zootopia' is Crushing It in Countries where Diversity Often Doesn't Play"

Based on the previous articles as mentioned above, it seems that most of the analysis of Zootopia are made as a film review. Although some of the reviews did mention Zootopia as a movie about racism but there are a few academic research paper which uses Zootopia as their object of research, more 
specifically with racism as the main topic of research. Zootopia is mentioned in Zurcher \& Robinson's "From "Bibbid-Bobbidi-Boo" to Scrooge: an update and comparative analysis of the portrayal of older characters in recent Disney animated films" and Zurcher, Brubaker, Webb \& Robinson's "Parental Roles in "The Circle of Life" Representations of Parents and Parenting in disney Animated Films from 1937 to 2017'. However, those researches put the emphasize on an entirely different point of view than what is done in this article.

The writer argues that discrimination and prejudices is something that can never be eliminated, unlike what Judy and Nick achieve. In order to be able to see the inconsistencies of a text, deconstruction will be used as a framework. Deconstruction, which is defined as reading the text against itself (Eagleton, 1995), "uncovers the unconscious rather than the conscious dimension of a text, all the things which its overt textuality glosses over or fails to recognize." (Barry, 1995, p. 71)

According to J. A. Cuddon in his Dictionary of Literary Terms, in deconstruction:

A text can be read as saying that something is quite different from what it appears to be saying... it may be reads as carrying a plurality of significance or as saying many different things which are fundamentally at variance with, contradictory to and subversive of what may be seen by criticism as a single 'stable' meaning. Thus a text may 'betray' itself. (Cuddon, 2013, p.189)

Fuchs and Ward (1994) also stated that in deconstruction, the main point is that "there are no firm "principles" and "doctrines" that could produce some stable and lasting order in the boomin' and buzzin' noise that is reality" which again emphasize how a text can be 'read' as having many interpretations.

Moreover, in other words, a deconstructionist practices what is called oppositional reading, which means "reading with the aim of unmasking internal contradictions or inconsistencies in the text, aiming to show the disunity which underlies it apparent unity." (Barry, 1995, p. 72).

Furthermore, Barry divided deconstruction process into three different stages, namely the verbal, the textual and the linguistic. The verbal stage is done through close reading or observation. It involves looking at the text for paradoxes or contradictions, at what might purely verbal level. The textual stage looks at the text in a more overall view. The deconstructionist will look for shifts or breaks in the continuity of the text. They may be shifts in focus, tone, point of view, attitude, etc. The textual stage show paradox and contradiction on a larger scale than is the case with the first stage, taking a broad view of the text as a whole. The last stage, the linguistic stage, involves looking for moments in the text when the adequacy of language itself as a medium of communication is called into question. (p. $74-76$ ) In this research, textual stage is the most appropriate one to be used as a movie is analyzed instead of a written text.

\section{METHOD}

This article is methodologically qualitative and interpretive by gathering the data qualitatively and presenting them descriptively. The writer uses library 
studies in conducting this research, beginning by watching Zootopia as the primary text. The research is continued by reading some references and browsing the internet for further information that can help to enrich the analysis. The writer analyzes the movie with the Theory of Deconstruction as a literary criticism.

\section{RESULTS AND DISCUSSION}

\section{What values does Zootopia offer as the surface meaning?}

As deconstruction is about finding how a text can 'betray' itself, the writer start this research about Zootopiaby describing how this movie, on its surface, support an idea which seems to become the main message that the movie would like to deliver, i.e. you can reach your dream and break the boundaries, overcome the stereotype and discrimination put around you because discrimination can be stopped and eliminated.

The message can be seen firstly, on their tagline, 'Anyone can be anything'. This means to encourage anyone or any animals in Zootopia that there is no boundaries. Second, still in relation to the tagline, the message is that discrimination and stereotyping can be eliminated in Zotopia, to be more specific, between the prey and the predator. Discrimination is "treatment or consideration of, or making a distinction in favor of or against, a person, or thing based on the group, class, or category to which that person or thing belongs rather than on individual merit." (Discrimination, n.d.)

While stereotype means "a simplified and standardized conception or image invested with special meaning and held in common by members of a group." (Stereotype, n.d.) A prey and small animals, for example, rabbits, mice, should be allowed to do predators' jobs, i.e. becoming a police officer, becoming leaders. A fox, for example, is not always cunning. A fox can lead an honest life. Third, there should not be any prejudice between animals. Prejudice is "unreasonable feelings, opinions, or attitudes, especially of a hostile nature, regarding an ethnic, racial, social or religious group." (Prejudice, n.d.) Animals in Zootopia live side by side in harmony. Predators should not consume or attack prey and preys are not victimized or objectified by predators.

This very message is conveyed through the two major characters in the movie, namely Judy Hoops and Nick Wilde. Judy Hoops is a rabbit who dares to dream big and defy the stereotype pinned to rabbits in general. Judy is also very positive and optimistic about the world around her. She truly believes that animals can get along well and be whatever they want to be without any restriction. This is clear even from the very start of the movie which shows little Judy, who takes part in a school performance that is used a vehicle to deliver her ideas:

YOUNG JUDY (CONT'D: Back then, the world was divided in two. Vicious predator or Meek prey.

(TWO BOXES drop down, labeled VICIOUS PREDATOR and MEEK PREY.

YOUNG JUDY (O.S.) (CONT’D): But over time, we evolved, and moved beyond our primitive savage ways. 
YOUNG JUDY (CONT'D): Now, predator and prey live in harmony. (Judy and the jaguar shake hands as the sheep throws glitter.) YOUNG JUDY (CONT'D): And every young mammal has multitudinous opportunities.

YOUNG JUDY: And I can make the world a better place! I am going to be...

(Catmull plays a 70s-style cop show theme on the boom box. Judy rips off her muumuu, revealing a POLICE OFFICER UNIFORM. 2.)

YOUNG JUDY (CONT'D): A police officer! (Howard\&Moore, 2016, 01: $44-02: 38)$

Judy's being highly optimistic with her world view is also very clear from the way she answers her parents' concern about her wish to become a police officer. Stu and Bonnie, her parents, reminds her that there has never been a bunny in the police force before, because rabbits are not meant to be a police officer. However, Judy does not see anything wrong with her wanting to become a police officer. She truly believes in the equality and that everyone gets the same chance of becoming what they want to be without any boundaries.

STU HOPPS: Right. There's never been a bunny cop.

BONNIE HOPPS: No.

STU HOPPS: Bunnies don't do that.

BONNIE HOPPS: Never.

STU HOPPS: Never.

YOUNG JUDY: Oh. Then I guess I'll have to be the first one.

Because I am gonna make the world...A better place! (03:38 - 03:46)

From the conversation above, it is obvious that the world around Judy may disagree with her point of view. Her parents, for example, are really concerned about Judy's wish of becoming a police officer. However, Judy manages to become a police officer after working hard and go against the doubts from everyone around her.

(Hopps and the comparatively huge CADETS sit in a circle as MAJOR FRIEDKIN, an intimidating drill instructor, lectures.)

(IN SAHARA SQUARE SIMULATOR: Hopps struggles through the sand.)

MAJOR FRIEDKIN(CONT'D: Scorching sandstorm. You're dead, bunny bumpkin!

(ON THE VINE-COVERED MONKEY BARS:Hopps swings across the bars, simulating the RAINFOREST DISTRICT. She falls off, landing face first in the mud.)

MAJOR FRIEDKIN (O.S.) (CONT'D): 1000 foot fall. You're dead, carrot face!

(TUNDRA TOWN ICE WALL: Judy and the cadets sprint toward the wall. The CLAWEDANIMALS dig into the ice wall. Hopps slides off.) MAJOR FRIEDKIN (CONT'D: Frigid ice wall. You're dead, farm girl!

(IN THE BOXING RING: Hopps gets in the ring with a BIG BISON.) MAJOR FRIEDKIN (CONT'D): E-normous criminal.

(Hopps gets punched in the nose.) 
Muljadi, EduLite: Journal of English Education, Literature, and Culture Vol.4, No.2, August 2019, 236-246 DOI: http://dx.doi.org/ 10.30659/e.4.2.236-246

MAJOR FRIEDKIN (CONT'D): You're dead!

(THREE QUICK CUTS OF FAILURE:)

MAJOR FRIEDKIN (O.S.) (CONT'D): Dead! / Dead! / Dead!

(IN THE TOILET: Hopps ruses into a stall. The toilet is considerably largerthan she is. She shuts the door. We see her climb up the toilet. In the next stall, we see the feet of a Hippo.Then, KERSPLASH! Hopps falls into the toilet.)

MAJOR FRIEDKIN (CONT'D): Filthy toilet. You're dead, fluff butt! (05:52 - 06:42)

However, despite the difficulties above, in the end, Judy overcomes all hardship in her training and graduates from the police academy. By doing so, Judy gives a hope and a proof to everyone that doubts her that she can be what she wants. Even after she becomes a police officer, she also manages to solve a case that no other officers can.

The next major character is Nick Wilde. Nick is a fox. He is a conman at the beginning of the movie. Unlike Judy, Nick does not believe that 'anyone can be anything' in Zootopia. His thought can be seen from the conversation he has with Judy on their first encounter and during their investigation together:

NICK: Alright look, everyone comes to Zootopia thinking they can be anything they want. Well you can't. You can only be what you are.

(points to himself) Sly fox.

(points to her) Dumb bunny.(25:32 - 25:43)

NICK: If the world's only gonna see a fox as shifty and

untrustworthy, there's no point in trying to be anything else.

HOPPS: Nick, you are so much more than that... (59:54 - 01:00:03)

However, after helping Judy solving the case of the missing predators, Judy offers Nick a chance to become her partner in the police department because she knows that actually Nick wanted to become a scout ranger in the past and did good but he gets disappointed by the treatment he receives from everyone around him who believes that a fox will stay sly and should not be trusted. With Judy, Nick can finally be what he wants to be and lead an honest life.

At the end of the movie, Judy and Nick become partners and they work together as police officers and the movie end in a happy ending for the two major characters. Based on this only, the writer can say that this movie has successfully delivered a message that discrimination, racism, prejudice can be eliminated when people stay true to themselves and are willing to work hard to achieve it.

\section{What values does Zootopia unconsciously reveal as the underlying meaning?}

The notion mentioned above is applicable only to the two major characters. It is true that the two major characters successfully get what they want, but there are more evidences in the movie that prove exactly the opposite of the surface idea in this movie thus making it impossible for the audience to get one absolute meaning or message that the film would like to convey. The 
writer believes even sometimes the film makers themselves are unaware of such a reading.

The first thing is that everyone around Judy and Nick find that making discriminative remarks, doing discriminative deed, having stereotype over certain types of animal are expected and normal. This is exactly the opposite of what Judy believes, unfortunately, only Judy realizes that this is wrong while the rest of the people around her do that. In other words, Judy is the minority here. In that case, the viewer of the movie may see that there is nothing wrong with doing such things because there are more animals doing that than believing that discrimination should be abolished. The first proof is from Judy's parents. At the beginning of the movie, Stu and Bonnie give advice to young Judy about her dream of becoming a police officer. They think that the way to be happy is to do what you are supposed to do.

Another thing that shows that discrimination and prejudice are considered normal in Zootopia can be seen in another scene from the movie. The scene is when Nick, at the beginning of the movie, tries to shop in Jumbeaux Café, owned by an elephant, Jerry Jumbeaux. Nick wants to buy a popsicle for Finnick, who pretends to be his toddler son. Jerry refuses to serve Nick simply because Nick is not an elephant. He also expresses his surprise that Nick dares to even try to shop there where he does not belong. It is clear from the scene that every animals have their own area and there is unwritten rule that they do not go to the other animals' places. In other words, every animal will stick to their area and property and no one dares to change that: JERRY JUMBEAUX, JR.: Listen, I don't know what you're doing skulking around duringdaylight hours, but I don't want any trouble in here... So hit the road.

NICK: I'm not looking for any trouble either, sir. I simply want to buy a Jumbo Pop for my little boy.

JERRY JUMBEAUX, JR.: Look, you probably can't read, fox but the sign says...(slowly reads SIGN, belittling)

WE RESERVE THE RIGHT TO REFUSE SERVICE TO ANYONE. So beat it. $(18: 37-19: 36)$

Back to the argument, this scene gives the impression that it is something expected that Nick, as a fox, should know where he belongs. He should not have gone to Jumbeaux Café as he should know it is not his place. When Nick tries to get out of his rightful place, what he does is wrong and it is not acceptable. Not to mention, Nick is there with a bad intention or to hustle thus he actually knows that he is not supposed to be there. This support the idea that every animal has their own limit and they should abide by it.

There are other scenes in the movie that also support the idea that discrimination, stereotyping and prejudice is accepted as something normal in Zootopia. One of the examples is when Judy first arrives at the precinct on her first day of work. There she meets Officer Clawhauser, a cheetah, who loves eating donuts and very talkative. Being talkative, in his speech, Clawhauser blurts out many things and he mentions discrimination, stereotyping, etc as if it were a fact of daily life. Again, this shows that discrimination has been a daily routine for Zootopians. 
Muljadi, EduLite: Journal of English Education, Literature, and Culture Vol.4, No.2, August 2019, 236-246 DOI: $h$ ttp://dx.doi.org/ 10.30659/e.4.2.236-246

HOPPS (O.C.): Scuse me! Down here? Hi.

(Clawhauser leans over the desk to find Hopps.)

CLAWHAUSER: O-M goodness! They really did hire a bunny.

What?!I gotta tell ya, you are even cuter than I thought you'd be.

HOPPS: (a little wince) Ooo, uh, you probably didn't know, but a

bunny can call another bunny "cute," but when other animals do it, it's a little...

(Clawhauser watches admiringly as she heads to the bullpen.)

CLAWHAUSER: (to himself, wistful)Aw... That poor little bunny's

gonna get eaten alive. $(13: 41-14: 31)$

Another thing from the movie that shows how it seems to be acceptable to stereotype or discriminate other animals in Zootopia can be seen from how the Mayor of Zootopia himself treats his assistant, Bellwhether. Bellwhether seems to willingly accept the treatment without any complaint although the viewers of the movie may not think so. In other words, Bellwether knows that she is a weak prey and she deserves to be treated in such a way by a predator, who is more dominant and presumably stronger.

\section{How do both values in Zootopia contradict themselves?}

All the scenes discussed above show how discrimination, stereotyping, and prejudice are done among the citizens of Zootopia. Considering that there are more scenes or events supporting this idea compared to the fact that only Judy who deliver the positive message about how she thinks that discrimination etc can be eliminated, then it can be strongly assumed that the message from Judy will be overlooked. Judy believes that when discrimination is eliminated, then the people can live side by side in harmony. However, based on the findings, what the viewers get is that discrimination cannot be eliminated. In order for the people to be able to live together harmoniously, everyone in Zootopia just has to know their own limit and boundaries. In that way, then order and peace can be achieved.

Furthermore, another scene almost at the end of the movie is worth mentioning. If Judy says that anyone can be anything in Zootopia, then the following event will become questionable. At the end of the movie, it turns out that it is Bellwether, the mayor assistant, who plans the whole scheme and turn predators into savages. She does that because she gets tired of everyone around her underestimating preys. What Bellwhether does is a crime. That is true. However, what Bellwhether does is actually putting predators into their primal origins. Predators are supposed to be wild and prey on preys but in Zootopia, predators cannot be predators anymore. They have to behave and control their 'animal' instinct. In other words, they cannot be themselves because there is a limit that predators cannot cross in Zootopia. This is exactly the opposite of what the character Judy conveys.

Moreover, Judy herself shows what is contradictory to what she believes in when she faces the press in a conference where she tries to explain what happens to all the missing predators. Without thinking and simply by expressing the first things that come across her mind, Judy mentions that the predators go savage because it is in their DNA. It is exactly the opposite of what she believes in but she says it anyway. Again, this shows a different message than what the film would like to convey from the very first place. 
REPORTER 2: Okay, so what is the connection?

HOPPS: Well, all we know is that they areall members of the predator family.

ANOTHER REPORTER: So, predators are the only onesgoing savage?

HOPPS: That is accu-- Yes, that is accurate. Yes...

REPORTER 3: Wow. Why is that happening?

HOPPS: We still don't know--

(More disappointed rumbling.)

(01: 10: $50-01: 11: 38)$

The last two events in the movie strengthen what this article propose. On the surface, Zootopia offers a positive view of the world, which probably apply to children. Through the major characters, especially Judy, this movie offers a message that you can be anything that you want. You can go against all odds and at the end you will be successful as long as you work hard. Discrimination, prejudice, and stereotyping should not stop you because they are wrong and you should prove it. When those sentiments are eliminated, then you can truly be whatever you want to be and live in harmony. However, adult viewers may find that Zootopia is a little bit more complicated than that. Other scenes and events in the movie support the idea that discrimination, stereotyping and prejudice have been going on for too long that they are considered as normal. Every animal has their own place and they should just abide by it. Problems only occur when there are animals who try to step out of their limit and boundaries, or in other worlds, their expected place. If only everyone knows their position, stay within it and be content with it, then everything will be in harmony.

\section{CONCLUSION}

Disney's Zootopia offers what animation movie goers expect to see. The movie is carefully plotted, beautifully designed, colorful, funny, and completed with the right amount of tension from whodunit twist. Children will love it even more because the characters are all animals. As a Disney movie, it is expected that this movie is filled with a lesson that warm up our hearts and a happy outcome that leaves children with positive messages about live and the world. Zootopia is no exception.

Based on the character Judy and what happens to her, the message of the movie can be clearly seen. Despite some difficulties, Judy successfully graduates from the police academy as top of her class. When she is underestimated because she is a bunny by her police chief, she solves a case that other officers - who are big animals like rhino, elephant, cheetah, and such- fail to solve. By doing so, Judy can stand strong in what she believes in, anyone can be anything. The message is very clear; discrimination, prejudice and stereotyping no longer apply. They should be abolished and all the animals can live in harmony.

However, The writer believes that other scenes, other characters, and events from the movie go against the very message. Discrimination, prejudice and stereotyping are the values that put the animals in check. Animals in Zootopia can live side by side because there are unwritten rules or social 
conventions based on those three sentiments that make it possible for the animals to live harmoniously.

Stu and Bonnie Hopps, Judy's parents, also the other rabbits, live as carrot farmers. The rabbits accept that they should be just carrot farmers and they want nothing else. Another example is what happen at the Jumbeaux café. Jerry Jumbeaux, who is an elephant and the owner of the café runs his business as usual. However, when Nick shows up at his café, then problems arise because Nick as a fox is not supposed to be there. He should shop somewhere else, not in a joint made for elephants. If only Nick stick to this unwritten rule based on discrimination, then no problems would arise.

A problem also has happened to Nick when he was young. He wants to become a scout rangers. It is implicitly stated in the movie that all the other scout rangers are preys. That is why when Nick decides to join the group, he is bullied. Nick supposed to know that as a predator, it is not acceptable for him to be scout rangers because scout rangers do good things and fox is mostly sly so he will not fit in. Nick s bullied because he does not know where he belongs based on prejudice that the other scout rangers believe in.

Having watched Zootopia and analyzed the scenes, the writer comes to a different conclusion. The order and harmony can be achieved not by abolishing discrimination, prejudice and stereotyping, but by making sure that everybody knows where his/her position is in the society. Everyone should know his limits especially if you are minority. In that way, preys and predators can live side by side peacefully. Discrimination, prejudice, stereotyping can never be abolished. It can only be repressed to such level that it no longer become a problem, either by making sure that everyone does their job or by ignoring it and accept it as facts.

As animation and children movies' lover, The writer is of the opinion that not all children movies are easy and should not be taken seriously. After all, what happens in Zootopia reflects what happens in our real world. Discrimination, stereotyping, and prejudice has been in practice for so long in our world and humans are divided in so many ways. If we believe that those practices cannot be stopped, like what happens in Zootopia, then perhaps a more pessimistic world view will flourish among us.

\section{REFERENCES}

Zootopia. (2016) Dir. Byron Howard, Rich Moore. Walt Disney Animation Studios.

Barry, Peter. (1995) Beginning Theory. United Kingdom: Manchester Unversity Press.

Cuddon, J. A. (2013) A Dictionary of Literary Terms and Literary Theory. $5^{\text {th }}$ ed. United Kingdom: Willey-Blackwell.

Discrimination. (n.d.) In Dictionary.com. Retrieved from https://www.dictionary.com/browse/discrimination

Eagleton, Terry. (1995) Literary Theory. An Introduction. United Kingdom: Blackwell Publishers. 
EduLite Journal of English Education, Literature, and Culture

Vol.4, No.2, August 2019, pp. 236-246

E-ISSN: 2528-4479, P-ISSN: 2477-5304

http://jurnal.unissula.ac.id/index.php/edulite

DOI: http://dx.doi.org/10.30659/e.4.2.236-246

Fuchs, S. \& Ward, S. (1994). What is Deconstruction, and where and when does it take place? Making facts in science, building cases in law. American Sociological Review, 59(4), 481-500.

Hipes, Patrick. (2016) AFI Awards: Best of 2016 Film List includes 'Silence', 'Hacksaw Ridge' \&More. Retrieved June 9, 2017, from https://www.yahoo.com/entertainment/afi-awards-best-film213416862.html.

Kermodode, Mark (March 27, 2016). Zootropolis review - Disney's animated odd couple has a perfect chemistry. Retrieved July 28, 2017 from https://www.theguardian.com/film/2016/mar/27/zootropolis-reviewdisney-animated-odd-couple-mark-kermode .

Prejudice. (n.d.) In Dictionary.com. Retrieved from https://dictionary.com/browse/prejudice.

Pressberg, Matt. (2016, August 4). Anti-Racist 'Zootopia' is Crushing It in Countries where Diversity Often Doesn't Play. Retrieved June 9, 2017 from https://ibtimes.com/anti-racist-zootopia-crushing -it-countrieswhere-diversity-often-doesnt-play-2350849.

$\begin{array}{llll}\text { Stereotype. } & \text { (n.d.) } & \text { InDictionary.com.Retrieved from }\end{array}$ https://www.dictionary.com/browse/stereotype.

Zurcher, J.D. \& Robinson, T. (2018). From "Bibbid-Bobbidi-Boo" to Scrooge: an update and comparative analysis of the portrayal of older characters in recent Disney animated films. Journal of Children and Media, 12(1), 115, DOI: 10.1080/17482798.2017.1331176.

Zurcher, J.D., Brubaker, P.J., Webb, S.M. \& Robinson, T. (2019). Parental Roles in "The Circle of Life" Representations of Parents and Parenting in Disney Animated Films from 1937 to 2017. Mass Communication and Society,DOI: 10.1080/15205436.2019.1616763. 